\title{
Evaluasi Kualitas Aset Destinasi Wisata Dayeuh Manggung Kabupaten Garut
}

\author{
Sania Oceana Dewi ${ }^{1}$, Hennidah Karnawati ${ }^{2}$ \\ ${ }^{1}$ Jurusan Administrasi Niaga, Politeknik Negeri Bandung, Bandung 40012 \\ E-mail : sania.oceana.mas17@polban.ac.id \\ ${ }^{2}$ Jurusan Administrasi Niaga, Politeknik Negeri Bandung, Bandung 40012 \\ E-mail : hennidah.karnawati@polban.ac.id
}

\begin{abstract}
ABSTRAK
Dayeuh Manggung merupakan salah satu destinasi wisata alam perkebunan di Kabupaten Garut. Destinasi wisata tersebut memiliki potensi untuk menjadi wisata kelas dunia karena keindahan dan kesejukan iklimnya. Pada destinasi wisata ini ada indikasi masalah: akses jalan menuju wisata berlubang di beberapa titik, jalur pejalan kaki licin untuk dilalui dan tidak terdapat railing (pegangan), serta beberapa fasilitas pendukung seperti meja piknik, fasilitas barbeque, fasilitas penyandang disabilitas, fasilitas P3K, toko cenderamata belum disediakan. Selain itu, wisatawan mengeluhkan jaringan seluler yang lemah bahkan cenderung tidak ada. Tujuan dari penelitian ini adalah untuk mengetahui kualitas aset wisata Dayeuh Manggung. Evaluasi kualitas aset wisata dilakukan berdasarkan 6 dimensi menurut Marzuki et al (2011 dan 2017): Aset Fisik, Aset Lingkungan, Fasilitas Utama, Fasilitas Pendukung, Infrastruktur, dan Aksesibilitas. Populasi penelitian ialah wisatawan yang pernah berkunjung pada tahun 2017-2019. Jumlah sampel penelitian diperoleh sebanyak 100 orang yang ditetapkan dengan teknik purposive sampling. Metode penelitian yang digunakan adalah deskriptif khususnya studi kasus dengan pendekatan kuantitatif dan kualitatif. Teknik pengumpulan data dilakukan melalui observasi, wawancara, studi dokumentasi dan kuesioner. Hasil penelitian menunjukkan bahwa kualitas aset infrastruktur baik, kulitas aset fisik, lingkungan dan aksesibilitas cukup baik, sedangkan kualitas fasilitas utama dan pendukung tidak baik.
\end{abstract}

Kata Kunci: Evaluasi Kualitas Aset; Destinasi Wisata

\section{PENDAHULUAN}

Semua aset yang dimiliki oleh pribadi atau kelompok (organisasi/perusahaan) perlu dikelola secara optimal, efektif dan efisien agar aset bernilai tinggi. Siklus hidup aset terdiri dari 8 tahap, yakni Strategy (Strategi), Plan (Perencanaan), Evaluation (Evaluasi), Create Procure (Pengadaan), Operate (Operasi), Maintain (Pemeliharaan), Modify (Modifikasi), dan Dispose (Penghapusan) [1]. Untuk mendapatkan nilai aset tertinggi dan terbaik, penggunaan dan pemanfaatan aset harus dilaksanakan secara optimal. Operasi aset perlu dilakukan terhadap aset wisata yang ada di Indonesia, karena aset-aset pada sektor pariwisata merupakan penyumbang devisa terbesar bagi Indonesia (Kemenparekaf, 2019).

Dayeuh Manggung merupakan wisata alam pertanian unggulan di Kabupaten Garut yang mampu menjadi destinasi wisata kelas dunia (Manteri Pariwisata, 2019). Menurut staf umum pengelola Dayeuh Manggung, tujuan wisata ini lebih banyak dikunjungi pada akhir pekan dan hari-hari besar seperti idul fitri, idul adha, dan tahun baru. Lokasinya yang dekat dengan jalan provinsi Garut-Tasik menjadi potensi besar untuk wisata ini. Selain itu, wisata Dayeuh
Manggung juga memiliki keindahan alam berupa hamparan perkebunan Teh, Jeruk, dan Alpukat, spot foto, keanekaragaman tanaman

hias, area rekreasi, dan beberapa bengunan peninggalan Belanda. Potensi dan keindahan alam yang dimiliki oleh wisata Dayeuh Manggung perlu di dukung oleh fasilitas, aksesibilitas, dan infrastruktur yang dapat menunjang kebutuhan wisatawan sehingga mereka betah dan berulang-ulang melakukan kunjungan wisata. Berdasarkan data hasil wawancara dan observasi terdahulu wisata Dayeuh Manggung memiliki beberapa indikasi masalah yakni adanya keluhan wisatawan mengenai fasilitas, rekreasi dan cakupan jaringan yang cukup sulit di jangkau pada wisata Dayeuh Manggung. Terdapat sampah atau limbah plastik di permukaan tanah khususnya area kemah. Terdapat lubang di beberapa titik jalan akses menuju objek wisata. Kondisi toilet umum kotor, bau, berlumut, dan cat triplex lapuk. Wisatawan merasa kesulitan untuk melewati jalur pejalan kaki karena licin dan tidak terdapat railing (pegangan). Tempat ibadah atau mushola kotor, bau, dan cat triplex sudah lapuk. Wisatawan penyandang disabilitas kesulitan untuk menggunakan fasilitas di 
wisata Dayeuh Manggung khususnya untuk berkeliling di area wisata dan saat menggunakan toilet. Fasilitas seperti meja piknik, fasilitas barbeque, fasilitas penyandang disabilitas, fasilitas $\mathrm{P} 3 \mathrm{~K}$, toko cenderamata, belum tersedia di wisata Dayeuh Manggung. Berikut merupakan kondisi aset wisata Dayeuh Manggung:

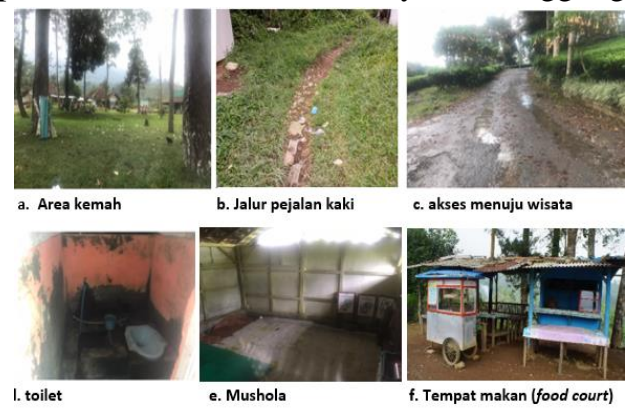

Gambar 1. Kondisi Aset Wisata Dayeuh Manggung Berdasarkan hasil wawancara terdahulu, dan permasalahan lapangan, maka untuk meningkatkan kualitas aset perlu dilakukan evaluasi terhadap aset wisata (Sugiama, 2013). Untuk mengevaluasi kondisi aset wisata dapat dilakukan pada 5 dimensi yakni Aset Fisik, Aset Lingkungan, Fasilitas Utama, Fasilitas Pendukung dan Infrastruktur) [2] atau dapat diukur melalui 3 dimensi yakni Fitur Fisik, Infrastruktur, dan Aksesibilitas [3]. Kajian awal untuk menilai kondisi aset wisata dilakukan melalui penelitian dengan judul "Evaluasi Kualitas Aset Destinasi Wisata Dayeuh Manggung Kabupaten Garut" dengan mengukur 6 dimensi yakni Aset Fisik, Aset Lingkungan, Fasilitas Utama, Fasilitas Pendukung, Infrastruktur dan Aksesibilitas.

\section{TINJAUAN PUSTAKA}

\subsection{Manajemen Aset}

Manajemen aset adalah rangkaian kegiatan mengelola kekayaan dimulai dari perencanaan kebutuhan aset hingga penghapusan aset agar dapat mencapai tujuan organisasi secara efektif dan efisien [4]. Pengelolaan aset perlu dilaksanakan sesuai dengan siklus aset yang diawali dengan proses perencanaan hingga penghapusan atau pembaharuan.

\subsection{Evaluasi Kualitas Aset Wisata}

Evaluasi adalah keputusan mengenai signifikansi, nilai, atau kualitas berdasarkan penelitian terhadap karakteristik-karakteristik yang baik dan buruk [5]. Evaluasi merupakan suatu proses atau kegiatan pemilihan, pengumpulan, analisis dan penyajian informasi yang dapat digunakan sebagai dasar dalam pengambilan keputusan serta dalam penyusunan suatu program selanjutnya [6].

Kualitas (Quality) merupakan suatu ukuran untuk menilai bahwa suatu barang atau jasa mempunyai nilai atau guna yang dikehendaki atau dianggap telah memiliki kualitas yang berfungsi seperti yang diinginkan [7]. Kualitas didefinisikan sebagai kesesuaian dengan persyaratan [8].

Aset adalah segala sesuatu yang memiliki nilai ekonomi, dapat dimiliki oleh individu, kelompok/perusahaan, atau oleh pemerintah dan dapat dinilai secara finansial (Sugiama, 2013). Aset fisik adalah item fisik yang memiliki umur ekonomis lebih dari satu tahun seperti, tanah, bangunan, pabrik, dan mesin [4].

Untuk mengevaluasi kualitas aset wisata alam dapat diukur melalui atribut wisata alam (NBT/Nature Based Tourim) yang terdiri dari 5 dimensi (Marzuki et al, 2017) dan 3 dimensi (Marzuki et al, 2011). Keduanya memiliki dimensi yang sama yakni infrastruktur. Maka, dimensi yang dievaluasi dalam penelitian ini terdiri dari 6 yakni, Aset Fisik (Physical Asset), Aset Lingkungan (Environment Asset), Fasilitas Utama (Main Facilities), Fasilitas Pendukung (Supporting Facilities), Infrastruktur (Infrastructure), dan Aksesibilitas (Accessibility). Untuk memperdalam kajian penelitian pada wisata Dayeuh Manggung, indikator setiap dimensi tersebut didukung oleh beberapa artikel/jurnal penelitian sebelumnya yang serupa yakni Alaeddinoglu dan Can (2011) dan Ginting \& Sasmita (2018). Berikut merupakan penjabaran indikator dari setiap dimensi.

Tabel 1 Dimensi dan Indikator Aset Wisata

\begin{tabular}{|c|c|}
\hline Dimensi & Indikator \\
\hline \multirow{3}{*}{$\begin{array}{l}\text { Aset Fisik (Physical Asset): Fisik adalah } \\
\text { fitur alam yang berada pada objek wisata } \\
\text { dan dapat menarik minat wisatawan [3]. }\end{array}$} & Varieties of plans species \\
\hline & $\begin{array}{l}\text { Varieties of recreational } \\
\text { avtivities }\end{array}$ \\
\hline & Adventure Opportunities \\
\hline \multirow{4}{*}{$\begin{array}{l}\text { Aset Lingkungan (Environment } \\
\text { Asset): } \\
\text { Lingkungan merupakan aset kehidupan } \\
\text { yang ditinggali oleh setiap makhluk hidup } \\
\text { dan harus dijaga kelestariannya. } \\
\text { Environment Quality (Kualitas } \\
\text { Lingkungan) mengacu pada kesejahtaraan } \\
\text { ekosistem di tempat wisata [9]. }\end{array}$} & $\begin{array}{l}\text { Cleanliness of water } \\
\text { bodies }\end{array}$ \\
\hline & Level of noise pollution \\
\hline & Level ground pollution \\
\hline & Level of land erosion \\
\hline \multirow{3}{*}{$\begin{array}{l}\text { Fasilitas utama (Main Facilities): Sarana } \\
\text { yang sangat dibutuhkan atau dirasa sangat } \\
\text { perlu/sangat penting pada suatu kawasan } \\
\text { wisata [10]. }\end{array}$} & Accommodation \\
\hline & $\begin{array}{l}\text { Food and bevarages } \\
\text { establishments }\end{array}$ \\
\hline & Toilets \\
\hline \multirow{11}{*}{$\begin{array}{l}\text { Fasilitas Pendukung (Supporting } \\
\text { Facilities): } \\
\text { Fasilitas pendukung merupakan sarana } \\
\text { yang berfungsi sebagai pelengkap fasilitas } \\
\text { utama sehingga wisatawan merasa lebih } \\
\text { ingin untuk tinggal lebih lama dan } \\
\text { hyaman di tempat wisata [10]. }\end{array}$} & Information Counter \\
\hline & Gazebo/Sitting Area \\
\hline & Picnic Table \\
\hline & Barbeque Facilities \\
\hline & Rubbish Bins \\
\hline & $\begin{array}{l}\text { Arrangements for The } \\
\text { Disabled }\end{array}$ \\
\hline & Emergency Aid Facilities \\
\hline & Fresh Drinking Water \\
\hline & Parking Area \\
\hline & Places of Workship \\
\hline & Souvenir Shops \\
\hline \multirow{3}{*}{$\begin{array}{l}\text { Infrastruktur (Infrastructure): } \\
\text { Infrastruktur pariwisata merupakan dasar } \\
\text { dari pengembangan pariwisata dan } \\
\text { pemanfaatan sumberdaya destinasi yang } \\
\text { ada [11] }\end{array}$} & Water Supply \\
\hline & Electrical Supply) \\
\hline & $\begin{array}{l}\text { Telecommunication } \\
\text { network coverage }\end{array}$ \\
\hline Aksesibilitas (Accessibilities): & Road Category \\
\hline
\end{tabular}




\begin{tabular}{|l|l|}
\hline \multicolumn{1}{|c|}{ Dimensi } & \multicolumn{1}{c|}{ Indikator } \\
\hline Aksesibilitas merupakan ketersediaanm & Proximity to City Center \\
\cline { 2 - 2 } keterjangkauan dan kenyamanan & $\begin{array}{l}\text { Proximity to other natural } \\
\text { infrastruktur transportasi (McMahon- }\end{array}$ \\
\cline { 2 - 2 } Beattie, 2012 dalam [12] & Comfort Level of The Road \\
\cline { 2 - 2 } & All Transorts Types \\
\hline
\end{tabular}

Sumber: Modifikasi Alaedinoglu \& Can (2011), Ginting dan Sasmita (2018), Marzuki et al (2011 dan 2017).

\section{METODE PENELITIAN}

\section{a. Jenis dan Teknik Pengumpulan Data}

Jenis metode penelitian yang digunakan yakni penelitian deskriptif dalam bentuk studi kasus, karena penelitian ini didasarkan pada fakta-fakta masa sekarang. Teknik pengumpulan data berupa wawancara ditujukan pada pengelola untuk mendapatkan data mengenai kondisi eksisting aset yang tidak bisa diperoleh dengan observasi maupun kuesioner, observasi, studi dokumentasi dan kuesioner.

\section{b. Teknik Analisis Data}

Penelitian ini menggunakan pendekatan kuantitatif dan kualitatif. Teknik kuantitatif dilakukan melalui analisis statistik dengan perhitungan Mean (rata-rata) dan Gap Analysis (analisis kesenjangan). Berikut merupakan penjelasan mengenai kedua metode tersebut.

\section{1) Mean (Rata-rata)}

Menentukan nilai rata-rata dari hasil data yang didapatkan melalui angket. Untuk mencari rata-rata tersebut dapat menggunakan rumus seperti berikut:

$$
\bar{X}=\frac{\sum X}{n}
$$

Keterangan:

$\bar{X}=$ Mean

$\mathrm{X}=$ Nilai Amatan

$\mathrm{n}=$ Jumlah Observasi

Berikut merupakan tafsiran nilai rata-rata berdasarkan pengukuran skala likert:

Tabel 2 Tafsiran Nilai Rata-rata

\begin{tabular}{|c|c|}
\hline Interval & Interpretasi \\
\hline $1,00-1,80$ & Sangat Tidak Setuju/Nyaman \\
\hline $1,81-2,60$ & Tidak Setuju/Nyaman \\
\hline $2,61-3,40$ & Cukup Setuju/Nyaman \\
\hline $3,41-4,20$ & Setuju/Nyaman \\
\hline $4,21-5,00$ & Sangat Setuju/Nyaman \\
\hline
\end{tabular}

Sumber: Umar (2011:130)

\section{2) Gap Analysis (Analisis Kesenjangan)}

Gap Analysis atau analisis kesenjangan dilakukan untuk menginterpretasi hasil penelitian dengan pendekatan kuantitatif maupun kualitatif berdasarkan observasi, wawancara dan kuesioner [13]. Tujuan perhitungan atau output yang dihasilkan dari perhitungan adalah kategori kualitas aset sudah baik, cukup baik/sedang, atau tidak baik melalui perhitungan sebagai berikut:

1. $\%$ Kualitas Indikator $=$ Jml. Kriteria Terpenuhi/Kriteria Keseluruhan x $100 \%$

2. $\%$ Kualitas Tiap Variabel $=\Sigma(\%$ Kualitas Tiap Indikator)/Jml. Indikator
3. $\%$ Kualitas Keseluruhan $=\Sigma(\%$ Kualitas Tiap Indikator)/Jml. Variabel

Hasil dari evaluasi kualitas aset wisata berdasarkan 6 dimensi yakni Physical Asset, Environment Asset, Main Facilities, Supporting Facilities, Infrastructure, dan Accessibility di interpretasikan ke dalam 3 kategori yakni Baik, Sedang/Cukup Baik, dan Tidak Baik berdasarkan nilai presentase yang diperoleh [14]. Hal tersebut dijelaskan dalam tabel 3.

Tabel 3 Interpretasi Kualitas Aset Wisata

\begin{tabular}{|c|c|}
\hline Presentase & Hasil Interpretasi/Kategori \\
\hline $100 \%$ & Baik \\
\hline $50 \%-99 \%$ & Sedang/Cukup Baik \\
\hline $0 \%-49 \%$ & Tidak Baik \\
\hline
\end{tabular}

Sumber: Gidlow (2012)

3) Analisis Deskriptif

Analisis deskriptif dengan data kualitatif meliputi reduksi data, penyajian data, dan penarikan kesimpulan.

\section{HASIL DAN PEMBAHASAN}

\subsection{Evaluasi Kualitas Aset Wisata}

Evaluasi dilakukan berdasarkan 6 dimensi yakni Aset Fisik, Aset Lingkungan, Fasilitas Utama, Fasilitas Pendukung, Infrastruktur dan Aksesibilitas. Berikut merupakan hasil penelitian dati 6 dimensi tersebut.

\section{Aset Fisik}

Evaluasi kualitas aset yang dilakukan pada dimensi aset fisik meliputi 3 indikator yakni variasi spesies tanaman, variasi aktivitas rekreasi dan peluang petualangan atau fasilitas bertualang seperti flying fox dan arena balap. Berikut merupakan hasil evaluasi kualitas aset dimensi aset fisik:

Tabel 4 Evaluasi Kualitas Aset Fisik

\begin{tabular}{|c|c|c|c|}
\hline Indikator & Kriteria & Interpretasi & $\begin{array}{c}\text { Hasil } \\
\text { Analisis }\end{array}$ \\
\hline $\begin{array}{l}\text { Variasi } \\
\text { Tanaman }\end{array}$ & $\begin{array}{l}\text { Terdapat spesies atau jenis } \\
\text { tanaman [2] }\end{array}$ & $\sqrt{ }$ & $\begin{array}{c}1 / 1 \times 10 \\
0 \%= \\
\mathbf{1 0 0 \%}\end{array}$ \\
\hline \multirow{5}{*}{$\begin{array}{l}\text { Variasi } \\
\text { Aktivitas } \\
\text { Rekreasi }\end{array}$} & $\begin{array}{l}\text { Fasilitas tea walk dapat } \\
\text { digunakan [2] }\end{array}$ & $\sqrt{V}$ & \multirow{5}{*}{$\begin{array}{c}3 / 5 \times \\
100 \% \\
= \\
60 \%\end{array}$} \\
\hline & $\begin{array}{l}\text { Fasilitas playground dapat } \\
\text { digunakan [2] }\end{array}$ & $\sqrt{ }$ & \\
\hline & $\begin{array}{l}\text { Fasilitas Spot Foto dapat } \\
\text { digunakan [2] }\end{array}$ & $\sqrt{ }$ & \\
\hline & $\begin{array}{l}\text { Taman dalam kondisi bersih } \\
\text { dan nyaman [2] }\end{array}$ & $x$ & \\
\hline & $\begin{array}{l}\text { Jalur Pejalan Kaki dapat } \\
\text { digunakan dengan nyaman } \\
{[15]}\end{array}$ & $x$ & \\
\hline \multirow[t]{2}{*}{$\begin{array}{l}\text { Peluang } \\
\text { Petualangan }\end{array}$} & $\begin{array}{l}\text { Fasilitas petualangan area } \\
\text { flying fox layak digunakan } \\
\text { [2] }\end{array}$ & $x$ & \multirow[t]{2}{*}{$\begin{array}{c}0 \times \\
100 \% \\
=0 \%\end{array}$} \\
\hline & $\begin{array}{l}\text { Fasilitas petualangan area } \\
\text { balap mini layak digunakan } \\
\text { [2] }\end{array}$ & $x$ & \\
\hline
\end{tabular}

Berdasarkan hasil evaluasi pemenuhan kriteria di atas, maka untuk menentukan presentase kualitas aset fisik pada wisata Dayeuh Manggung dihitung sebagai berikut: 
Tabel 5 Presentase Kualitas Aset Fisik

\begin{tabular}{|l|c|c|}
\hline \multicolumn{1}{|c|}{ Indikator } & Presentase & Interpretasi \\
\hline Variasi Spesies Tanaman & $100 \%$ & Baik \\
\hline Variasi Aktivitas Rekreasi & $60 \%$ & Tidak Baik \\
\hline Peluang Petualangan & $0 \%$ & Tidak Baik \\
\hline Mean (Rata-rata) & $\mathbf{5 3 , 3 \%}$ & Cukup Baik \\
\hline
\end{tabular}

\section{Aset Lingkungan}

Evaluasi kualitas aset yang dilakukan pada dimensi aset lingkungan terdiri dari 4 indikator yakni, kebersihan badan air, tingkat polusi suara, tingkat pencemaran tanah, dan tingkat erosi tanah. Berikut merupakan hasil evaluasi kualitas aset lingkungan pada wisata Dayeuh Manggung:

Tabel 6 Hasil Evaluasi Kualitas Aset Lingkungan

\begin{tabular}{|l|l|c|c|}
\hline \multicolumn{1}{|c|}{ Indikator } & \multicolumn{1}{|c|}{ Kriteria } & $\begin{array}{c}\text { Inter } \\
\text { pretasi }\end{array}$ & $\begin{array}{c}\text { Hasil } \\
\text { Analisis }\end{array}$ \\
\hline Kebersihan & Tidak Berbau [2] & $\sqrt{ }$ & $3 / 3 \times 10$ \\
Badan Air & Tidak Berasa [2] & $\sqrt{ }$ & $0 \%=$ \\
& Tidak Berwarna [2] & $\sqrt{ }$ & $100 \%$ \\
\cline { 2 - 3 } & Tidak ada polusi suata yang & $\sqrt{ }$ & $1 / 1 \times$ \\
Tingkat & diakibatkan oleh kontruksi atau & & $100 \%$ \\
& lalu lintas [2] & & $=$ \\
& & & $100 \%$ \\
\hline Tingkat & Tidak ada limbah domestic [16] & $\mathrm{x}$ & $2 / 3 \times$ \\
Pencemaran & Tidak ada limbah industry [16] & $\sqrt{ }$ & $100 \%$ \\
Tanah & Tidak ada limbah pertanian [16] & $\sqrt{ }$ & $=$ \\
& & & $66.7 \%$ \\
\hline Tingkat Erosi & Tidak ada perubahan permukaan & $\sqrt{ }$ & $1 / 1 \mathrm{x}$ \\
Tanah & tanah [2] & & $100 \%$ \\
& & & $=$ \\
& & & $100 \%$ \\
\hline
\end{tabular}

Berdasarkan hasil evaluasi pemenuhan kriteria di atas, maka untuk menentukan presentase kualitas aset lingkungan dihitung sebagai berikut:

Tabel 7 Presentase Kualitas Aset Lingkungan

\begin{tabular}{|l|c|c|}
\hline \multicolumn{1}{|c|}{ Indikator } & Presentase & Interpretasi \\
\hline Kebersihan Badan Air & $100 \%$ & Baik \\
\hline Variasi Aktivitas Rekreasi & $100 \%$ & Baik \\
\hline Peluang Petualangan & $66,7 \%$ & Cukup Baik \\
\hline Tingkat Polusi Suara & $100 \%$ & Baik \\
\hline Mean (Rata-rata) & $\mathbf{9 1 , 6 7 5 \%}$ & Cukup Baik \\
\hline
\end{tabular}

\section{Fasilitas Utama}

Evaluasi kualitas aset yang dilakukan pada dimensi fasilitas utama terdiri dari 3 indikator yakni akomodasi, tempat makan, dan toilet. Berikut merupakan hasil evaluasi kualitas aset fasilitas utama pada wisata Dayeuh Manggung:

Tabel 8 Hasil Evaluasi Kualitas Fasilitas Utama

\begin{tabular}{|l|l|c|c|}
\hline Indikator & \multicolumn{1}{|c|}{ Kriteria } & Interpretasi & $\begin{array}{c}\text { Hasil } \\
\text { Analisis }\end{array}$ \\
\hline \multirow{5}{*}{ Akomodasi } & Terdapat penginapan [2] & $\mathrm{x}$ & $0 / 3 \mathrm{x}$ \\
& Tidak bumi perkemahan yang & $\mathrm{x}$ & 100 \\
& aman, terawat, menyediakan & & $0 \%$ \\
& komponen akses, toilet, toilet & & \\
& bilas, dan layout [2] & & \\
\cline { 2 - 3 } & Terdapat mobil caravan [2] & $\mathrm{x}$ & \\
\hline Rumah & Terdapa kedai makanan dengan & $\mathrm{x}$ & $0 / 2 \mathrm{x}$ \\
Makan & menyeduakan 5-20 jenis makanan & & 100 \\
& berbeda [17] & & $\%=$ \\
\cline { 2 - 3 } & Memiliki papan petunjuk arah & $\mathrm{x}$ & $0 \%$ \\
& dan papan nama [17] & $\mathrm{x}$ & $0 / 4 \mathrm{x}$ \\
\hline Toilet & Kondisi toilet bersih [17] & & \\
\end{tabular}

\begin{tabular}{|c|c|c|c|}
\hline Indikator & Kriteria & Interpretasi & $\begin{array}{c}\text { Hasil } \\
\text { Analisis }\end{array}$ \\
\hline & $\begin{array}{l}\text { Terpisah untuk wanita dan pria } \\
\text { [17] }\end{array}$ & $\mathrm{X}$ & \multirow{3}{*}{$\begin{array}{l}100 \\
\%= \\
0 \%\end{array}$} \\
\hline & $\begin{array}{l}\text { Menyediakan toilet disabilitas } \\
\text { [17] }\end{array}$ & $\mathrm{x}$ & \\
\hline & $\begin{array}{l}\text { Terdapat fasilitas papan nama } \\
\text { yang jelas, air bersih yang cukup, } \\
\text { tempat cuci tangan (wastafel) dan } \\
\text { pengering, kloset, tempat sampah } \\
\text { tertutup, tempat buang air kecil } \\
\text { (urinoir) untuk toilet pengunjuk } \\
\text { pria, dan sirkulasi udara serta } \\
\text { pencahayaan yang baik [17] }\end{array}$ & $\mathrm{x}$ & \\
\hline
\end{tabular}

Berdasarkan hasil evaluasi pemenuhan kriteria di atas, maka untuk menentukan presentase kualitas aset fasilitas utama dihitung sebagai berikut:

Tabel 9 Presentase Kualitas Fasilitas Utama

\begin{tabular}{|c|c|c|}
\hline Indikator & Presentase & Interpretasi \\
\hline Akomodasi & $0 \%$ & Tidak Baik \\
\hline Tempat Makan & $0 \%$ & Tidak Baik \\
\hline Toilet & $0 \%$ & Tidak Baik \\
\hline Mean (Rata-rata) & $\mathbf{0 \%}$ & Tidak Baik \\
\hline
\end{tabular}

\section{Fasilitas Pendukung}

Evaluasi kualitas aset yang dilakukan pada dimensi fasilitas pendukung terdiri dari 11 indikator. Berikut merupakan hasil evaluasi kualitas aset fasilitas pendukung pada wisata Dayeuh Manggung:

Tabel 10 Hasil Evaluasi Kualitas Fasilitas Pendukung

\begin{tabular}{|c|c|c|c|}
\hline Indikator & Kriteria & Interpretasi & Hasil Analisis \\
\hline \multirow[t]{3}{*}{$\begin{array}{l}\text { Tempat } \\
\text { Informasi }\end{array}$} & $\begin{array}{l}\text { Tersedia tempat informasi } \\
\text { [2] }\end{array}$ & $\mathrm{x}$ & \multirow[t]{3}{*}{$\begin{array}{c}0 / 3 \times 100 \% \\
=0 \%\end{array}$} \\
\hline & $\begin{array}{l}\text { Luas tempat informasi }<= \\
80 \mathrm{~m}^{2}[17]\end{array}$ & $\mathrm{x}$ & \\
\hline & $\begin{array}{l}\text { Menyediakan fasilitas } \\
\text { seperti Telepon, Internet, } \\
\text { Komputer, Printer, } \\
\text { Scanner, Meja, Kursi/Sofa, } \\
\text { Materi promosi pariwisata, } \\
\text { Peta, Peralatan Keamanan, } \\
\text { Instalasi listrik, P3K dan } \\
\text { APAR [17] }\end{array}$ & $\mathrm{x}$ & \\
\hline Gazebo & $\begin{array}{l}\text { Tersedia tempat berlindung } \\
\text { seperti gazebo }(2 \mathrm{~m} \times 3 \mathrm{~m}) \\
\text { dan tempat duduk [17] }\end{array}$ & $\sqrt{ }$ & $\begin{array}{c}2 / 2 \times 100 \% \\
= \\
100 \%\end{array}$ \\
\hline $\begin{array}{l}\text { Meja } \\
\text { Piknik }\end{array}$ & $\begin{array}{l}\text { Tersedia meja piknik yang } \\
\text { dilengkapi kursi [17] }\end{array}$ & $\mathrm{x}$ & $\begin{array}{c}0 / 1 \times 100 \% \\
=0 \%\end{array}$ \\
\hline \multirow{2}{*}{$\begin{array}{l}\text { Fasilitas } \\
\text { Barbeque }\end{array}$} & Tersedia cincin api [18] & $\mathrm{x}$ & \multirow{2}{*}{$\begin{array}{c}0 / 2 \times 100 \% \\
=0 \%\end{array}$} \\
\hline & $\begin{array}{l}\text { Tersedia alat memanggang } \\
{[18]}\end{array}$ & $\mathrm{x}$ & \\
\hline \multirow[t]{2}{*}{$\begin{array}{l}\text { Tempat } \\
\text { Sampah }\end{array}$} & $\begin{array}{l}\text { Teempat sampah terdiri } \\
\text { dari organik dan non- } \\
\text { organik [17] }\end{array}$ & $\sqrt{ }$ & \multirow[t]{2}{*}{$\begin{array}{c}1 / 2 \times 100 \% \\
=50 \%\end{array}$} \\
\hline & $\begin{array}{l}\text { Tempat sampah tersedia } \\
\text { setiap } 20 \mathrm{~m} \text { [17] }\end{array}$ & $\mathrm{x}$ & \\
\hline \multirow{3}{*}{$\begin{array}{l}\text { Fasilitas } \\
\text { penyandang } \\
\text { disabilitas }\end{array}$} & $\begin{array}{l}\text { Tersedia toilet disabilitas } \\
\text { [17] }\end{array}$ & $\mathrm{x}$ & \multirow{3}{*}{$\begin{array}{c}0 / 3 \times 100 \% \\
=0 \%\end{array}$} \\
\hline & $\begin{array}{l}\text { Tersedia jalur disabilitas } \\
\text { [17] }\end{array}$ & $\mathrm{x}$ & \\
\hline & $\begin{array}{l}\text { Tersedia tempat parkir } \\
\text { disabilitas [17] }\end{array}$ & $\mathrm{x}$ & \\
\hline $\begin{array}{l}\text { Fasilitas } \\
\text { P3K }\end{array}$ & Tersedia fasilitas P3K [19] & $\mathrm{x}$ & $\begin{array}{c}0 / 1 \times 100 \% \\
=0 \%\end{array}$ \\
\hline
\end{tabular}




\begin{tabular}{|l|l|c|c|}
\hline \multicolumn{1}{|c|}{ Indikator } & \multicolumn{1}{|c|}{ Kriteria } & Interpretasi & Hasil Analisis \\
\hline $\begin{array}{l}\text { Fasilitas air } \\
\text { minum }\end{array}$ & $\begin{array}{l}\text { Tersedia fasilitas Air } \\
\text { Minum [19] }\end{array}$ & $\begin{array}{c}1 / 1 \times 100 \% \\
=100 \%\end{array}$ \\
\hline $\begin{array}{l}\text { Tempat } \\
\text { Parkir }\end{array}$ & $\begin{array}{l}\text { Tersedia tempat parkir } \\
\text { dengan petunjuk arah pola } \\
\text { parkir yang jelas [17] }\end{array}$ & $\mathrm{x}$ & $\begin{array}{c}0 / 2 \times 100 \% \\
=0 \%\end{array}$ \\
\cline { 2 - 3 } & $\begin{array}{l}\text { Tersedia tempat parkir arah } \\
\text { pola parkir yang jelas [17] }\end{array}$ & $\mathrm{x}$ & \\
\hline $\begin{array}{l}\text { Tempat } \\
\text { Ibadah }\end{array}$ & $\begin{array}{l}\text { Tersedia tempat ibadah } \\
\text { yang bersih dan terawat, } \\
\text { tempat wudhu yang } \\
\text { terpisah untuk pria, wanita } \\
\text { dan penyandang disabilitas } \\
{[17]}\end{array}$ & $\mathrm{x}$ & $\begin{array}{c}0 / 3 \times 100 \% \\
=0 \%\end{array}$ \\
\hline $\begin{array}{l}\text { Toko } \\
\text { suvenir }\end{array}$ & $\begin{array}{l}\text { Tersedia toko } \\
\text { cinderamata/souvenir }[17]\end{array}$ & $\mathrm{x}$ & $0 / 1 \times 100 \%$ \\
& & & \\
\hline
\end{tabular}

Berdasarkan hasil evaluasi pemenuhan kriteria di atas, maka untuk menentukan presentase kualitas aset fasilitas pendukung dihitung sebagai berikut.

Tabel 11 Presentase Kualitas Fasilitas Pendukung

\begin{tabular}{|l|c|c|}
\hline \multicolumn{1}{|c|}{ Indikator } & Presentase & Interpretasi \\
\hline Tempat Informasi & $\mathbf{0 \%}$ & Tidak Baik \\
\hline Gazebo/ Tempat Duduk & $\mathbf{1 0 0 \%}$ & Baik \\
\hline Meja Piknik & $\mathbf{0 \%}$ & Tidak Baik \\
\hline Fasilitas Barbeque & $\mathbf{0 \%}$ & Tidak Baik \\
\hline Tempat Sampah & $\mathbf{5 0 \%}$ & Cukup Baik \\
\hline $\begin{array}{l}\text { Fasilitas Penyandang } \\
\text { Disabilitas }\end{array}$ & $\mathbf{0 \%}$ & Tidak Baik \\
\hline Fasilitas P3K & $\mathbf{0 \%}$ & Tidak Baik \\
\hline Fasilitas Air Minum & $\mathbf{1 0 0 \%}$ & Baik \\
\hline Tempat Parkir & $\mathbf{0 \%}$ & Tidak Baik \\
\hline Tempat Ibadah & $\mathbf{0 \%}$ & Tidak Baik \\
\hline Toko Cinderamata & $\mathbf{0 \%}$ & Tidak Baik \\
\hline \multicolumn{1}{|c|}{ Mean (Rata-rata) } & $\mathbf{1 4 . 5 4 \%}$ & Tidak Baik \\
\hline
\end{tabular}

\section{Infrastruktur}

Evaluasi kualitas aset yang dilakukan pada dimensi infrastruktur terdiri dari 3 indikator yakni persediaan air, persediaan listrik, dan cakupan jaringan telekomunikasi. Berikut merupakan hasil evaluasi kualitas aset infrastruktur:

Tabel 12 Hasil Evaluasi Kualitas Infrastruktur

\begin{tabular}{|c|c|c|c|}
\hline Indikator & Kriteria & Interpretasi & $\begin{array}{c}\text { Hasil } \\
\text { Analisis }\end{array}$ \\
\hline \multirow[t]{3}{*}{ Persediaan Air } & $\begin{array}{l}\text { Persediaan air bersih } \\
\text { dapat memenuhi } \\
\text { kebutuhan }[20]\end{array}$ & $\sqrt{ }$ & \multirow[t]{3}{*}{$\begin{array}{c}3 / 3 \times 100 \\
\%= \\
100 \%\end{array}$} \\
\hline & $\begin{array}{l}\text { Jaringan air dibangun di } \\
\text { dalam tanah [20] }\end{array}$ & $\sqrt{ }$ & \\
\hline & $\begin{array}{l}\text { Pembangunan jaringan } \\
\text { berpedoman pada } \\
\text { ketentuan teknis dari } \\
\text { instansi yang berwenang } \\
{[20]}\end{array}$ & $\sqrt{ }$ & \\
\hline \multirow[t]{3}{*}{$\begin{array}{l}\text { Persediaan } \\
\text { Listrik }\end{array}$} & $\begin{array}{l}\text { Persediaan listrik dapat } \\
\text { memenuhi kebutuhan } \\
{[20]}\end{array}$ & $\sqrt{ }$ & \multirow[t]{3}{*}{$\begin{array}{c}3 / 3 \times 100 \\
\%= \\
100 \%\end{array}$} \\
\hline & $\begin{array}{l}\text { Jaringan listrik dibangun } \\
\text { di dalam tanah }[20]\end{array}$ & $\sqrt{ }$ & \\
\hline & $\begin{array}{l}\text { Pembangunan jaringan } \\
\text { berpedoman pada } \\
\text { ketentuan teknis dari } \\
\text { instansi yang berwenang } \\
{[20]}\end{array}$ & $\sqrt{ }$ & \\
\hline Cakupan & Cakupan jaringan dapat & $\sqrt{ }$ & $3 / 3 \times 100$ \\
\hline
\end{tabular}

\begin{tabular}{|l|l|c|c|}
\hline \multicolumn{1}{|c|}{ Indikator } & \multicolumn{1}{|c|}{ Kriteria } & Interpretasi & $\begin{array}{c}\text { Hasil } \\
\text { Analisis }\end{array}$ \\
\hline $\begin{array}{l}\text { Jaringan } \\
\text { Telekomunikasi }\end{array}$ & $\begin{array}{l}\%= \\
\text { memenuhi kebutuhan }\end{array}$ & $\begin{array}{c}\% \\
{[20]}\end{array}$ & $\sqrt{ }$ \\
\cline { 2 - 3 } & $\begin{array}{l}\text { Jaringan telefon } \\
\text { dibangun di dalam tanah } \\
{[20]}\end{array}$ & \\
\cline { 2 - 3 } & $\begin{array}{l}\text { Pembangunan jaringan } \\
\text { berpedoman pada } \\
\text { ketentuan teknis dari } \\
\text { instansi yang berwenang } \\
{[20]}\end{array}$ & $\sqrt{\mid}$ & \\
\hline
\end{tabular}

Berdasarkan hasil evaluasi pemenuhan kriteria di atas, maka untuk menentukan presentase kualitas aset infrastruktur dihitung sebagai berikut:

Tabel 13 Perhitungan Presentase Kualitas Infrastruktur

\begin{tabular}{|l|c|c|}
\hline \multicolumn{1}{|c|}{ Indikator } & Presentase & Interpretasi \\
\hline Persediaan Air & $100 \%$ & Baik \\
\hline Persediaan Listrik & $100 \%$ & Baik \\
\hline Cakupan Jaringan Telekomunikasi & $100 \%$ & Baik \\
\hline \multicolumn{1}{|c|}{ Mean (Rata-rata) } & $\mathbf{1 0 0 \%}$ & Baik \\
\hline
\end{tabular}

\section{Aksesibilitas}

Evaluasi kualitas aset yang dilakukan pada dimensi aksesibilitas terdiri dari 4 indikator yakni kategori jalan, jarak ke pusat kota, jarak ke sumber daya alam atau sejarah lainnya, tingkat kenyamanan jalan, dan semua jenis transportasi. Berikut merupakan hasil evaluasi kualitas aksesibilitas pada wisata Dayeuh Manggung:

Tabel 14 Hasil Evaluasi Kualitas Aksesibilitas

\begin{tabular}{|l|l|c|c|}
\hline \multicolumn{1}{|c|}{ Indikator } & \multicolumn{1}{|c|}{ Kriteria } & $\begin{array}{c}\text { Inter } \\
\text { pretasi }\end{array}$ & $\begin{array}{c}\text { Hasil } \\
\text { Analisis }\end{array}$ \\
\hline Ketgori Jalan & Lebar Jalan > 3,5 m [3] & $\sqrt{ }$ & $\begin{array}{c}1 / 1 \times 100 \\
\%= \\
\mathbf{1 0 0 \%}\end{array}$ \\
\hline Jarak ke pusat & Akses untuk menuju pusat kota & $\sqrt{ }$ & $1 / 1 \mathrm{x}$ \\
kota & dari objek wisata dekat dan & & $100 \%=$ \\
& mudah ditempuh [19] & & $\mathbf{1 0 0 \%}$ \\
\hline Jarak ke & Wisata memiliki jarak dekat & $\sqrt{ }$ & $1 / 1 \times$ \\
sumber daya & dengan wisata alam lainnya/ & & $100 \%=$ \\
alam lainnya & tempat bersejarah lainnya [19] & & $100 \%$ \\
\hline Tingkat & Jalan provinsi Garut-Tasik & $\sqrt{ }$ & $1 / 2 \times$ \\
kenyamanan & nyaman untuk dilewati [19] & & $100 \%=$ \\
jalan & Jalan pedesaan nyaman untuk & $\mathrm{x}$ & $50 \%$ \\
\cline { 2 - 3 } & dilewati [19] & & \\
\hline
\end{tabular}

Berdasarkan hasil evaluasi pemenuhan kriteria di atas, maka untuk menentukan presentase kualitas aset aksesibilitas dihitung sebagai berikut:

Tabel 15 Presentase Kualitas Aksesibilitas

\begin{tabular}{|l|c|c|}
\hline \multicolumn{1}{|c|}{ Indikator } & Presentase & Interpretasi \\
\hline Kategori Jalan & $100 \%$ & Baik \\
\hline Jarak ke Pusat Kota & $100 \%$ & Baik \\
\hline $\begin{array}{l}\text { Jarak ke Sumber Daya Alam atau } \\
\text { Sejarah Lainnya }\end{array}$ & $100 \%$ & Baik \\
\hline Tingkat Kenyamanan Jalan & $50 \%$ & Cukup Baik \\
\hline \multicolumn{1}{|c|}{ Mean (Rata-rata) } & $\mathbf{8 7 . 5 \%}$ & Cukup Baik \\
\hline
\end{tabular}

Berdasarkan hasil perhitungan di atas, diketahui bahwa presentase aset fisik sebesar 53,3\% yang artinya kualitas dimensi tersebut cukup baik, presentase aset lingkungan sebesar $91,675 \%$ artinya kualitas dimensi 
tersebut cukup baik, presentase fasilitas utama sebesar $0 \%$ yang artinya dimensi tersebut tidak baik, presentase fasilitas pendukung sebesar $14,54 \%$ artinya kualitas dimensi tersebut tidak baik, presentase infrastruktur $100 \%$ artinya kualitas dimensi tersebut sudah baik, dan presentase aksesibilitas sebesar $87,5 \%$ artinya kualitas dimensi tersebut cukup baik. Maka, rata-rata presentase dari 6 dimensi yakni aset fisik, aset lingkungan, fasilitas utama, fasilitas pendukung, infrastruktur dan aksesibilitas sebesar $57,84 \%$ yang artinya kualitas aset wisata cukup baik.

Menurut Suminasih dan Ichniarsyah (2021) dan Arifin dkk (2016), wisata alam jenis agrowisata yang memiliki tujuan untuk memberikan edukasi kepada wisatawan perlu memiliki aset fasilitas yang dapat menunjang kegiatan tersebut seperti greenhouse dan taman edukasi. Namun, fasilitas tersebut belum tersedia di wisata Dayeuh Manggung [21][22]

\subsection{Alternatif Pemecahan Masalah}

Berdasarkan permasalahan yang teridentifikasi pada aset fasilitas pada destinasi wisata Dayeuh Manggung maka perlu dilakukan pengembangan aset untuk mengoptimalkan aset-aset fasilitas pada wisata tersebut. Alternatif dapat dilakukan dengan membuat perencanaan pengembangan aset fasilitas destinasi wisata Dayeuh Manggung.

\section{KESIMPULAN}

Berdasarkan hasil evaluasi mengenai kualitas aset pada wisata Dayeuh Manggung Kabupaten Garut dengan mangukur 6 dimensi dapat disimpulkan bahwa Kualitas aset wisata Dayeuh Manggung berdasarkan dimensi Aset Fisik, Aset Lingkungan dan Aksesibilitas cukup baik. Kualitas aset wisata Dayeuh Manggung berdasarkan dimensi Fasilitas Utama dan Fasilitas Pendukung tidak baik. Kualitas aset wisata Dayeuh Manggung berdasarkan dimensi Infrastruktur baik. Maka, secara keseluruhan kualitas aset destinasi wisata Dayeuh Manggung dapat dinyatakan cukup baik.

Dari simpulan di atas, maka dapat diketahui mayoritas permasalahan ada pada aset fasilitas utama dan pendukung wisata Dayeuh Manggung. Maka, pemecahan masalah tersebut adalah menyusun rencana pengembangan aset fasilitas wisata Dayeuh Manggung. Rencana pengembangan dapat dilakukan dengan menyesuaikan dengan konsep yang sesuai dengan karakterstik objek.

\section{DAFTAR PUSTAKA}

[1] J. D. Campbell, A. K. S. Jardine, and J. McGlynn, ASSET MANAGEMENT Life-Cycle Decisions. 2011.

[2] A. Marzuki, M. Khoshkam, D. Mohamad, and I. Abdul Kadir, "Linking nature-based tourism attributes to tourists' satisfaction," Anatolia, vol.
28, no. 1, pp. 96-99, 2017, doi: 10.1080/13032917.2016.1277432.

[3] A. Marzuki, A. A. Hussin, B. Mohamed, A. G. Othman, and A. P. M. Som, "Assessment of nature-based tourism in South Kelantan, Malaysia," Tourismos, vol. 6, no. 1, pp. 281-295, 2011.

[4] N. A. J. Hastings, Physical Asset Management. 2015.

[5] J. Planologi, R. Annisa, T. Angestiwi, P. Studi, M. Aset, and P. Negeri, "EVALUASI ASET FASILITAS PADA WANAWISATA PUNCELING DI Wanawisata Punceling adalah objek wisata yang dimiliki Kesatuan Pemangkuan Hutan," vol. 17, no. 2, pp. 198-215, 2020.

[6] F. F. Slamet and N. Fadjarwati, "Evaluasi Kinerja Aset Fasilitas Wisata Domba di Kabupaten Garut," J. Manaj. Aset Infrastruktur Fasilitas, vol. 4, no. 3, pp. 183-194, 2020, doi: 10.12962/j26151847.v4i3.7099.

[7] P. R. E. Mamesah, "Pengaruh Kualitas Pelayanan Terhadap Kepuasan Pelanggan pada Hotel Lucky Inn Manado," J. Adm. Bisnis, vol. 1, no. 1, pp. 46$52,2020$.

[8] K. Letelay and S. N. Azhari, "Evaluasi Kualitas Perangkat Lunak dengan Metrics Berorientasi Objek," Semin. Nas. Inform. ..., vol. 2012, no. semnasIF, pp. 139-145, 2015, [Online]. Available: http://103-23-20-

161.isi.cloud.id/index.php/semnasif/article/view/1 091.

[9] J. Priskin, "Assessment of natural resources for nature-based tourism: The case of the Central coast region of Western Australia," Tour. Manag., vol. 22, no. 6, pp. 637-648, 2001, doi: 10.1016/S02615177(01)00039-5.

[10] M. Raja, K. Di, D. Buantan, and B. Kabupaten, "No Title," vol. 2, 2015.

[11] M. Ramyar and N. Halim, "Tourist Expectation and Satisfaction towards Existing Infrastructure and Facilities in Golestan National Park, Iran," no. July, 2020, [Online]. Available: www.arjhss.com.

[12] C. H. Chin, F. Y. Law, M. C. Lo, and T. Ramayah, "The Impact of Accessibility Quality and Accommodation Quality on Tourists' Satisfaction and Revisit Intention to Rural Tourism Destination in Sarawak: The Moderating Role of Local Communities' Attitude," Glob. Bus. Manag. Res., vol. 10, no. 2, pp. 115-127, 2018.

[13] Y. Muchsam, Falahah, and G. I. Saputro, "Penerapan Gap Analysis Pada Pengembangan Sistem Pendukung," Semin. Nsional Apl. Teknol. Inf., vol. 2011, no. September 2020, p. A-94-A$100,2011$.

[14] C. J. Gidlow, N. J. Ellis, and S. Bostock, "Corrigendum to 'Development of the Neighbourhood Green Space Tool (NGST)' [Landscape Urban Plan. 106 (2012) 347-358]," Landsc. Urban Plan., vol. 110, no. 1, pp. 183-185, 2013, doi: 10.1016/j.landurbplan.2012.10.001.

[15] S. J. H. AlKahtani, J. Xia, B. Veenendaaland, C. 
Caulfield, and M. Hughes, "Building a conceptual framework for determining individual differences of accessibility to tourist attractions," Tour. Manag. Perspect., vol. 16, pp. 28-42, 2015, doi: 10.1016/j.tmp.2015.05.002.

[16] M. muslimah Muslimah, "Dampak Pencemaran Tanah Dan Langkah Pencegahan," J. Penelit. Agrisamudra, vol. 2, no. 1, pp. 11-20, 2017, doi: 10.33059/jpas.v2i1.224.

[17] K. P. D. E. Kreatif, "Struktur Organisasi Kementerian Pariwisata dan Ekonomi Kreatif / Badan Pariwisata dan Ekonomi Kreatif Republik Indonesia," 2020.

[18] U.S. Department of the Interior Bureau of Reclamation, "Recreation Facility Design Guidelines," no. April, 2002.

[19] F. Alaeddinoglu and A. S. Can, "Identification and classification of nature-based tourism resources: Western Lake Van basin, Turkey," Procedia - Soc. Behav. Sci., vol. 19, pp. 198-207, 2011, doi: 10.1016/j.sbspro.2011.05.124.

[20] Menteri Lingkungan Hidup dan Kehutanan, "Peraturan Menteri Lingkungan Hidup dan Kehutanan No P.32/MenLHK/Setjen/Kum.1/3/2016," Kementeri. Lingkung. Hidup dan Kehutan., p. 69, 2016.

[21] Arifin, M., Rianto. E, Agung, Djoko, Surono, Armis, dam Suzanna. "Pengembangan kawasan agroeduwisata banyumulek kecamatan kediri kabupaten lombok barat provinsi nusa tenggara barat," 2016.

[22] I. H. Sumiasih and A. N. Ichniarsyah, "The Design and Concept of Agro-Edutourism Park Using Sustainable Agriculture Principle at Attaqie Farm," IOP Conf. Ser. Earth Environ. Sci., vol. 709, no. 1, 2021, doi: 10.1088/1755-1315/709/1/012016. 